\title{
“QUEM É HOMOSSEXUAL CARREGA CONSIGO O FARDO DO PRECONCEITO”: VIOLÊN- CIAS CONTRA ADOLESCENTES E JOVENS HOMOSSEXUAIS E A REDE DE APOIO SOCIAL
}

\author{
Marta Angélica lossi Silva ${ }^{1}$
}

\begin{abstract}
BRAGA, I.F. Quem é homossexual carrega consigo o fardo do preconceito: violências contra adolescentes e jovens homossexuais e a rede de apoio social. Tese (Doutorado). Programa de Pós-Graduação Enfermagem em Saúde Pública da Escola de Enfermagem de Ribeirão Preto - EERP/ USP. Universidade de São Paulo, 2017. 179p.
\end{abstract}

A tese de doutorado intitulada Quem é homossexual carrega consigo o fardo do preconceito: violências contra adolescentes e jovens homossexuais e a rede de apoio social ${ }^{2}$, defendida por lara Falleiros Braga junto ao Programa de Pós-Graduação Enfermagem em Saúde Pública da Escola de Enfermagem de Ribeirão Preto da Universidade São Paulo - EERP/USP sob a orientação da Profa. Dra. Marta Angélica lossi Silva, teve como objetivo geral compreender as experiências de violência por adolescentes e jovens homossexuais, no contexto da rede de apoio social, sob a perspectiva analítica Queer.

A autora entrevistou 12 adolescentes e jovens gays e lésbicas, com idades entre 14 e 24 anos. Além das entrevistas, mapas de rede social foram utilizados como instrumento para a coleta de dados, a fim de compreender e analisar a rede e o apoio social que os adolescentes e jovens homossexuais obtiveram para o enfrentamento à violência.

A introdução da tese apresenta a contextualização dos conceitos de adolescência, juventude, homossexualidade, violência, homofobia e apoio social, bem como faz uma análise e contextualização acerca das políticas públicas e programas voltados para a população de Lésbicas, Gays, Bissexuais, Travestis, Transexuais e Transgêneros (LGBT) no Brasil, analisando os avanços e retrocessos na busca pela efetivação dos direitos desta população. Em seguida, a autora apresenta e discute o estado da arte acerca da rede e do apoio social voltados aos adolescentes e jovens homossexuais frente às situações de violência e a produção científica nacional e internacional sobre violência contra adolescentes e jovens homossexuais.

O marco teórico se embasa na teoria Queer, uma abordagem pós-estruturalista, mediada pelo debate sobre a não essencialização dos sujeitos, questionando a construção das identidades sociais fixas, a estrutura social binária e heteronormativa, bem como a compreensão de sexo e gênero enquanto constructos sociais. Foi apresentada uma contextualização do surgimento dessa concepção teórica, dos principais autores que a embasam e os seus conceitos teóricos, tais como: heteronormatividade, heterossexualidade compulsória, abjeção, o armário enquanto dispositivo de manutenção do segredo da sexualidade homossexual; bem como contemplou o debate sobre a não essencialização dos sujeitos e a fixidez nos modelos binários.

Os dados foram analisados de acordo com os pressupostos do método de interpretação de sentidos, por meio do qual foi possível identificar quatro núcleos de sentido: 1. Experiência de violências sofridas: "O homossexual que aparenta ser homossexual, vai carregar o fardo do preconceito, da discriminação até a morte", neste núcleo discute-se as vivências de violência experienciadas pelos adolescentes e jovens entrevistados,

${ }^{1}$ Enfermeira professora associada da Escola de Enfermagem de Ribeirão Preto da Universidade de São Paulo, Ribeirão Preto, São Paulo, Brasil. E-mail: maiossi@eerp.usp.br

${ }^{2}$ Este estudo recebeu apoio financeiro da Fundação de Amparo à Pesquisa do Estado de São Paulo (Fapesp), por meio de concessão de bolsa de Doutorado a autora da Tese (Processo n. 2014/00701-1). As opiniões, hipóteses e conclusões ou recomendações expressas neste material são de responsabilidade da autora e não necessariamente refletem a visão da Fapesp. 
evidenciando-se diversos tipos de violências às quais foram expostos na vida; 2 . Experiências de saída do "armário": "Ele disse que eu era louco, disse que eu não estava são, que eu não estava com muita certeza", explora as experiências dos adolescentes e jovens no processo de assumir-se enquanto homossexuais às suas famílias; 3 . Masculinidades e Feminilidades: "Os meninos sofrem muito mais, por ter que mostrar a virilidade, tem que exalar masculinidade", analisa as relações que os adolescentes e jovens participantes da pesquisa estabeleceram entre a violência vivenciada e as relações de gênero; e 4. Rede e Apoio Social: "A maior fonte de apoio são os amigos que são homossexuais, porque a gente se identifica por passar por problemas parecidos", apresenta e discute a configuração das redes sociais significativas para os adolescentes e jovens no enfrentamento à violência, levando-se em conta os Mapas de Rede, complementados pelos dados provenientes das entrevistas.

Os resultados revelam que há a perpetuação de uma cultura heteronormativa e violenta, que sanciona punições aos dissidentes da norma heterossexual, e que os adolescentes e jovens que não seguem a linearidade entre sexo, gênero, desejo e práticas sexuais, quanto mais a quebram, mais serão subalternizados, sendo submetidos aos diversos tipos de violência em espaços públicos e privados. Essas situações de violência são reforçadas pela falta de acesso aos serviços e instituições de apoio social. São as figuras femininas, amigos e profissionais distintos - tais como psicólogos e enfermeiros, que são reconhecidos como as principais fontes de apoio social para os participantes. No entanto, apesar de alguns serviços de saúde terem sido acionados pelos participantes do estudo, não foram suficientes para o enfrentamento à violência e para a promoção da saúde.

Dessa forma, as conclusões da tese apontam para a precariedade no acesso à rede social e na efetivação do apoio social, pois, sua composição e articulação não foi eficiente no enfrentamento da violência sofrida. A autora pontua ainda, a necessidade dos profissionais que atuam com esta população, sobretudo professores, equipes de saúde e da assistência social, estarem preparados para o acolhimento, atendimento, orientações às famílias, fortalecimento dos vínculos familiares e encaminhamento de casos de vio- lência, favorecendo a desconstrução das posturas heteronormativas e homofóbicas em busca da efetivação dos direitos dos adolescentes e jovens homossexuais.

A autora sugere que os conhecimentos advindos da tese sejam considerados na implementação de políticas públicas e na efetivação daquelas políticas já preconizadas, bem como na sensibilização e desenvolvimento de profissionais e práticas de cuidado e atenção à família, ao adolescente e ao jovem homossexual, contribuindo para o combate à violência homofóbica e para a promoção da saúde. Sugere ainda que novos estudos sejam conduzidos para apoiar os conceitos e resultados discutidos e expandir as reflexões sobre as experiências de adolescentes e jovens homossexuais que vivenciam a violência, por meio de diferentes abordagens teórico-metodológicas e atores sociais.

Contatos com a autora da tese:

lara Falleiros Braga

Terapeuta Ocupacional, doutora em Ciências pelo Programa de Pós-Graduação em Enfermagem em Saúde Pública - EERP/USP. Atualmente é professora adjunta do Departamento de Terapia Ocupacional da Universidade Federal da Paraíba.

E-mail: iarafalleiros@gmail.com 